\title{
ICT new tools for a sustainable textile and clothing industry
}

DOI: 10.35530/IT.071.05.1811

\author{
MANUELA AVADANEI \\ SABINA OLARU \\ IRINA IONESCU \\ LUMINITA CIOBANU \\ LIDIA ALEXA \\ ALEXANDRA LUCA
}

\author{
MARIANA URSACHE \\ MONICA OLMOS \\ THEOFILOS ASLANIDIS \\ DANA BELAKOVA \\ CÉSAR SILVA
}

\section{ABSTRACT - REZUMAT}

\section{ICT new tools for a sustainable textile and clothing industry}

Sustainability in the textile and clothing industry is seen as a subject of the major producers, with many brands divulging their concern about protecting people and the environment and adopting an environmental friendly communication approach. For companies in the textile and clothing sector (especially SMEs), the circular economy provides an opportunity to create new profit streams, increase their resilience to volatile input costs, and support their efforts to become completely sustainable and socially responsible.

EU textile and clothing industry needs a flexible workforce that can respond to the development and to the globalised market and the need for sustainable design and manufacturing in order to respond to the global demand for sustainable creative products. In this frame, it is important to have suitable tools to train the employees, to prepare them to deal with these new challenges, to enhance their knowledge, and to develop new skills and competencies for this new type of business. This paper introduces a new training toolkit, which will contribute to the training process of the personnel involved in the textile and clothing industry. This toolkit contains e-learning courses in six European languages, mainly various sources (books, video) and activities (quizzes and forums), which are uploaded and available on the Udemy platform.

Keywords: sustainability expert, sustainable management, environmental performance, corporate social responsibility, circular economy

Noi instrumente TIC pentru o industrie textilă și de îmbrăcăminte sustenabilă

Sustenabilitatea în industria textilă și de îmbrăcăminte este percepută ca o preocupare a marilor producători, multe mărci dezvăluind îngrijorarea lor cu privire la protejarea populației și a mediului și adoptarea unei abordări de comunicare ecologice. Pentru companiile din sectorul textile și îmbrăcăminte (în special IMM-uri), economia circulară oferă o oportunitate de a crea noi fluxuri de profit, de a-și spori rezistența la costurile volatile și de a-și sprijini eforturile de a deveni complet sustenabile și responsabile social.

Industria textilă și de îmbrăcăminte europeană are nevoie de o forță de muncă flexibilă care să poată răspunde dezvoltării și pieței globalizate și nevoii de proiectare și fabricație durabile, pentru a satisface cererea globală de produse creative sustenabile. În acest context, este important să existe instrumente adecvate pentru a instrui angajații, pentru a-i pregăti să facă față acestor noi provocări, pentru a acumula cunoștințe și pentru a dezvolta noi abilități și competențe pentru acest nou tip de afacere. Această lucrare introduce un nou set de instrumente de formare, care vor contribui la procesul de instruire a personalului implicat în industria textilă și de îmbrăcăminte. Acest set de instrumente conține cursuri de e-learning în șase limbi europene, în principal diverse surse (cărți, videoclipuri) și activități (teste și forumuri), care sunt disponibile pe platforma Udemy.

Cuvinte-cheie: expert în sustenabilitate, management sustenabil, perfomanță de mediu, responsabilitate socială corporativă, economie circulară

\section{INTRODUCTION}

The sustainability concept refers to the physical preservation of human societies and their cultures, institutions, social orders and regimes. Behavioural, cultural psychological and institutional factors influenced how individuals understand and implement their economic and environmental businesses and the need for sustainable goals and practices [1]. According to the European Commission, "Sustainable development means meeting the needs of the present while ensuring future generations can meet their own needs" [2].

Sustainability is no longer a concern of environmentalists and ecologists and has become a concern of individuals. Sustainability defines, in fundamental ways, the communities in which we live and is the source of renewable and non-renewable resources on which civilisation depends. Health and well-being, economy, and social life and safety, all require a highquality environment [3]. Sustainable development 


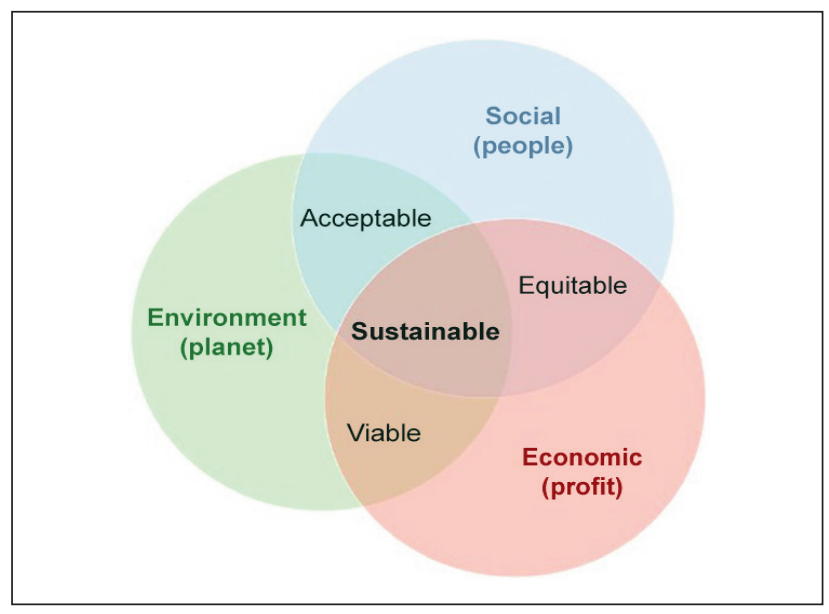

Fig. 1. The three pillars of sustainability [4]

has evolved as a concept through several decades of profound international scientific debate, and it has acquired distinct political connotations in the context of globalisation. The concept of sustainability consists of three pillars: economic, environmental, and social-also known informally as profits, planet, and people (figure 1) [4].

The textile and clothing industry is a part of the European manufacturing industry which has to become sustainable, too. This is a diverse and heterogeneous industry covering numerous activities. In 2019, the entire EU-27 T\&C industry represented a turnover of $€ 162$ billion and 160,000 compamies, mainly SMEs [5-6].

The textile industry is, after oil, the second most polluting industry in the world. Many companies have understood the concept of "fast fashion" as a continuous production of clothing items and of control [7]. Ecological and social problems strongly affect the T\&C market. The three main concerns are production ecology, human ecology and waste disposal [8]. In this context, the textile industry is committed to change its vision, to start on producing echo-friendly textiles and sustainable in order to face global competition [9].

Companies and consumers are more concerned about sustainability nowadays. The clothing industry is receiving more attention due to mass production and its significant impact on the planet. Fashion brands are introducing sustainable lines and circular economies in their business model to reduce their energy consumption, advocating for environmental protection and other activities [10].

The European Commission recently published the report "Mapping sustainable fashion opportunities for SMEs" which emphasises that the transformation of companies towards more sustainable and resourceefficient business models not only helps to protect the environment, but also provides a competitive advantage by creating important cost savings and boosting innovation for sustainability [11].

Also, the European Commission patronized different initiatives and projects in the field of sustainability, to help textile companies (SME's) and countries to reach new opportunities for their business (table 1). In the Paris' Agreement [11] there are mentioned some key points to sustain SME's for adopting sustainable/circular business models, such as:

- economic instruments through tax incentives, grants and subsidies for sustainable initiatives,

\begin{tabular}{|r|l|}
\hline \multicolumn{2}{|c|}{ PROJECTS ON EUROPEAN LEVEL FOCUSED ON SUSTAINABILITY CONCEPT [11] } \\
\hline Project title & WORTH Pilot Project \\
\hline Partners & London College of Fashion, University of the Arts London; Institut Francais de la Mode; Euratex \\
\hline Funder/s & $\begin{array}{l}\text { Funded by the Competitiveness and Innovation Framework Programme (CIP) of the European } \\
\text { Commission's Directorate General for Enterprise and Industry }\end{array}$ \\
\hline Duration & 2013-2015 \\
\hline Project link & http://www.pilot.worth-project.eu/project-design-craft-manufacturereurope/worth-projects-2.html \\
\hline $\begin{array}{r}\text { Summary of main } \\
\text { focus/aims }\end{array}$ & $\begin{array}{l}\text { Cross border innovation partnerships between manufacturing enterprises and designers, product } \\
\text { innovation across Europe; Involved 79 SMEs and 34 European partnerships between designers } \\
\text { footwear, eyewear, furniture, fur, leather industries from different EU countries (and other CIP } \\
\text { participating countries) for innovative product development, positioning in the market, } \\
\text { presentation in trade fairs and exhibitions and IP rights support }\end{array}$ \\
\hline Project title & WORTH Partnership Project \\
\hline Partners & Textile Technology Institute AITEX, KEPA, IED, DAG Communication \\
\hline Funder/s & COSME \\
\hline Duration & Ongoing \\
\hline Project link & https://www.worthproject.eu/ \\
\hline $\begin{array}{r}\text { Summary of main } \\
\text { focus/aims }\end{array}$ & $\begin{array}{l}\text { Initiation and support for collaborations on the transnational level between designers and other } \\
\text { creatives, SME's manufacturers and technology firms in the areas of fashion and textiles, } \\
\text { footwear, furniture/home decoration, leather/fur, jeweller, accessories; focus on SME's and start-ups }\end{array}$ \\
\hline
\end{tabular}




\begin{tabular}{|c|c|}
\hline Project title & Textile and Clothing Business Labs (TCBL) \\
\hline Partners & $\begin{array}{l}\text { City of Prato, German Institutes for Textile and Fiber Research - Center for Management } \\
\text { Research (DIFT), Instituto Superiore Mario Boella, Skillaware, The Open University, IMEC, } \\
\text { Tavistock Institute, Materials Industrial Research \& Technology Center S.A. (MIRTEC), Waag } \\
\text { Society, Huddersfield \& District Textile Training Company Ltd, The elnstitute (eZavod), Consorzio } \\
\text { Arca, Unioncamere del Veneto (UCV), Hellenic Clothing Industry Association, Sanjotec - Centro } \\
\text { Emresarial e Tecnológico, Clear Communication Associates Ltd, Oxford Brookes University, } \\
\text { Association Reginnova NE, Centre Scientifique \& Technique de I'Industrie Textile Belge, Institut } \\
\text { Français de la Mode (IFM), Institut d'Arquitectura Avancada de Catalunya - Fundacio Privada } \\
\text { (FabTextiles), Cleviria, Sqetch BV }\end{array}$ \\
\hline Funder/s & $\mathrm{H} 2020$ \\
\hline Duration & $2015-2019$ \\
\hline Project link & https://tcbl.eu/ \\
\hline $\begin{array}{r}\text { Summary of main } \\
\text { focus/aims }\end{array}$ & $\begin{array}{l}\text { Building an ecosystem of enterprises, innovation labs, service providers and business advisors } \\
\text { to foster change in the textiles and clothing industry and explore innovative business models }\end{array}$ \\
\hline Project title & Trash2Cash (T2C) \\
\hline Partners & $\begin{array}{l}\text { Centre for Circular Design, Chelsea School of Arts, University of the Arts London; RISE - } \\
\text { Research Institutes of Sweden }\end{array}$ \\
\hline Funder/s & H2020 NMP \\
\hline Duration & $2015-2018$ \\
\hline Project link & https://www.trash2cashproject.eu/ \\
\hline $\begin{array}{r}\text { Summary of main } \\
\text { focus/aims }\end{array}$ & Create newly regenerated fibres from preconsumer and post-consumer waste \\
\hline
\end{tabular}

carbon taxes and penalties for non-sustainable operations, appropriate finance and grants, including repayable finance and patient capital;

- information flows through improving textiles collection and recycling statistics and reporting, creating knowledge and resource sharing platforms and connecting networks, sustainable businesses with suppliers, markets and funding opportunities, education for sustainability and public information campaigns;

- regulatory instruments/policy through creating clear end-of-waste criteria for textiles to facilitate upcycling of waste, mandatory EPR Schemes and harmonising regulations across EU and removing administrative barriers;

- technological developments through access to design and manufacturing tools, information on and access to emerging R\&D e.g into recycling;

- collaboration and mentoring schemes through the enhanced cooperation of small and large players, alignment of values across the supply chain and dedicated mentoring for fashion start-ups.

These goals can be reached with a trained employee, who must have up-to-date skills and knowledge to be able to create sustainable products which have to meet the global market demands. It is rather challenging to take the employees from their workplace and to enrol them into a full training programme. It is also a known fact, that if the theory is combined with practice, the trainee's level of understanding increases, he becomes more confident and willing to learn and to apply what he was taught to.

At European level, several projects were or are focused to define the necessary and needed job profiles, and new qualifications, and adequate curricula were designed for these in order to train employees. The required curricula for bringing up-to-date or acquiring knowledge and skills is uploaded on different online educational platforms. In this and way, the learner has the possibility to personalise his training path, to select and combine which courses/ module he needs to study, to establish his goals and methods for reaching them.

In table 2 there are listed some European projects, in which it was or will be described and defined new jobs and/or qualifications, required nowadays and in the near future in the field of textile and clothing industry, and in which was developed the correspondent curricula for training the learners.

We can say that, at the European level, there are initiatives for helping SMEs to train and adapt employees (new jobs or qualifications) to the new economic requirements. As it is shown in table 1, the project ECO TEX is a European project which is focused on designing, developing and testing a new job qualification profile and corresponding training curricula on the subject of "How to implement circular economy techniques in Textiles Industry". This new job is based on the development of new skills and competences of the workforce, which will help the individual to face and deal with all new challenges.

\section{METHODOLOGY FOR DESIGNING THE PROFILE OF "SUSTAINABILITY EXPERT"}

For the textile and clothing sector companies (especially SMEs), the circular economy provides an opportunity to create new profit streams, increases their resilience to volatile input costs, and supports 


\begin{tabular}{|c|c|}
\hline \multicolumn{2}{|r|}{ PROJECTS FOCUS ON NEW UPDATED PROFILES [12-14] } \\
\hline Project title & Skills4Smart TCLF Industries 2030 \\
\hline Partners & $\begin{array}{l}\text { Euratex, European Confederation of the Footwear Industry (CEC), COTANCE, CIAPE, CITEVE, } \\
\text { Centrul National de Dezvoltare a Invatamantului Profesional si Tehnic (CNDIPT), TRAING } \\
\text { CENTRE FOR THE BELGIAN TEXTILE INDUSTY-COBOT, CTCP - Centro Tecnológico do } \\
\text { Calçado de Portugal, Hellenic Management Association, Fundación Estatal para la Formación en } \\
\text { el Empleo, IVOC, INESCOP, UNITEX, PIN - SERVIZI DIDATTICI E SCIENTIFICI PER } \\
\text { L'UNIVERSITÀ DI FIRENZE, POLITECNICO CALZATURIERO, SPIN360, Universitatea Tehnica } \\
\text { Gheorghe Asachi din lasi (TUIASI), Lodz University of Technology (TUL), Universitat Politècnica } \\
\text { de Catalunya, PIRIN-TEX EOOD, Universitat de Lleida, VIRTUAL CAMPUS }\end{array}$ \\
\hline Funder/s & Erasmus+ \\
\hline Duration & 2018-2021 \\
\hline Project link & http://www.s4tclfblueprint.eu/ \\
\hline $\begin{array}{r}\text { Summary of main } \\
\text { focus/aims }\end{array}$ & $\begin{array}{l}\text { Enhance the modernisation and competitiveness of the EU Textile, Clothing, Leather, and Footwear } \\
\text { (TCLF) sectors through the development of a sustainable upskilling and reskilling strategy, which } \\
\text { is supported by a communication campaign to attract social, economic and political actors. } \\
\text { Identification of } 8 \text { new TCLF job profiles - and corresponding curricula (EQF and ECVET based) } \\
\text { in line with the sector changing needs in short to longer-term. Design of } 8 \text { new courses including } \\
\text { MOOCs/VOOCs or MOOCs (part online/in school) or serious games or similar tools }\end{array}$ \\
\hline Project title & Circular Economy Innovative Skills in the Textile Sector - ECOTEX \\
\hline Partners & $\begin{array}{l}\text { Confederación de la Industria Textil - TEXFOR, CITEVE, Hellenic Fashion Industry Association } \\
\text { (SEPEE), Riga Technical University (RTU), "Gheorghe Asachi" Technical University of lasi (TUIASI) }\end{array}$ \\
\hline Funder/s & Erasmus+ \\
\hline Duration & $2017-2020$ \\
\hline Project link & http://www.ecotexerasmus.eu/en/ \\
\hline $\begin{array}{r}\text { Summary of main } \\
\text { focus/aims }\end{array}$ & $\begin{array}{l}\text { Design and implementation of an innovative and comprehensive training toolkit. The platform will } \\
\text { focus on online training and will facilitate the dissemination of knowledge and sharing of } \\
\text { experience. Moreover, it will serve as a medium for all stakeholders in the field to share concerns } \\
\text { and advice, as well as promote employment opportunities. } \\
\text { Define a professional profile for "Sustainability expert". }\end{array}$ \\
\hline Project title & Innovative design practices for achieving a new textile circular sector-Design4Circle \\
\hline Partners & $\begin{array}{l}\text { Riga Technical University (RTU), "Gheorghe Asachi" Technical University of lasi (TUIASI), } \\
\text { ECORES SPRLP, Innovative Business Association of Furniture Manufacturers and related in the } \\
\text { Murica Region (Amuebla), Footwear Technology Centre of Portugal (CTCP)., Textile Trade } \\
\text { Association - Textile Cluster (TTA-TC) }\end{array}$ \\
\hline Funder/s & Erasmus+ \\
\hline Duration & $2018-2020$ \\
\hline Project link & https://design4circle.eu/ \\
\hline $\begin{array}{r}\text { Summary of main } \\
\text { focus/aims }\end{array}$ & $\begin{array}{l}\text { Design4Circle aims to cover the skill gaps in the eco-innovation of European Designers in textile } \\
\text { and fashion products. Design4Circle will allow designers from the textile sector sectors to reduce } \\
\text { environmental impact during the products life-cycle, and develop new and innovative businesses } \\
\text { within the principles of the circular economy. }\end{array}$ \\
\hline Project title & Clothing Technician Profile Update via Education - CosTUmE \\
\hline Partners & CITEVE, MODATEX, ATP, INOVA+, AITEX, ASECOM, INCDTP, ASTRICO NE \\
\hline Funder/s & Erasmus+ \\
\hline Duration & $2018-2020$ \\
\hline Project link & http://clothingtechnician.eu/ \\
\hline $\begin{array}{r}\text { Summary of main } \\
\text { focus/aims }\end{array}$ & $\begin{array}{l}\text { Create a new and attractive Clothing Technician profile and qualification recognised in EU (PT, } \\
\text { ES, RO) and to mobilise young people and adults in their professional qualification in the VET } \\
\text { system, through the acquisition of necessary skills for textile and clothing industry, by the strong } \\
\text { connection to fashion, technical textiles, home textiles, sustainability, the introduction of new } \\
\text { materials and industry } 4.0 \text {. }\end{array}$ \\
\hline
\end{tabular}


their efforts to become completely sustainable and socially responsible.

Skilled and well-qualified workers can play a critical role in addressing these barriers and creating opportunities to guide the shift to circularity. Indeed, the Textile Sector requires a more qualified workforce to deal with new technologies, stimulate innovation, ensure quality management and develop international strategies and marketing. Therefore, the availability of adequately skilled workers has become one of the major issues for the Textile industry as the majority of the companies still face the shortage of trained and qualified personnel in green and circular economy techniques, in both design and manufacturing. In this framework, the project ECO TEX has as its main objective the development, design and implementation of an innovative and comprehensive training protocol, a work-based training ICT tool for the Textile Industry. This methodology is the result of joint work carried out under partnership. The methodology is characterised by the realisation of Textile Industry's needs for new education and training systems and tools for their existing and potential workforce in order to meet the demands and requirements of the market, for new designed sustainable products and circular economy guidelines performance.

To reach its goal, to define a new job qualification which will try to cover the gaps between the new business requirements and professional level of the workers, the project methodology was:

- Researching on anticipating skills based on evidence;

- Designing and defining the professional qualification profile of "Sustainability Expert" for textile and clothing sector;

- Development of a training toolkit able to cope with the identified training needs, according to European Common Framework on Vocation, Educational Training (ECVET);

- Development of innovative training units and elearning courses;

- Development of a digital training platform as an innovative open distance - learning ICT tool and test the results.

The methodology used to anticipate the needed skills of a Sustainability Expert in the textiles and clothing sector was based on desk research employing qualitative methods by using a questionnaire with 5 sections:

- Section 1: General information about the company (company size; product/ service and location);

- Section 2: Information about the concept of sustainability - starting from the definition of Sustainability of the World Commission on Environment and Development;

- Section 3: Information on if companies consider the sustainability concept in their business strategy;

- Section 4: Why is sustainability important for companies;

- Section 5: What skills the Sustainability Experts should have - rank the importance of skills and competencies of the Sustainability Expert.

This questionnaire was applied in textile and clothing companies of the partner countries: Spain, Greece, Romania, Latvia and Portugal. All answers were analysed and interpreted, and the conclusions were used to design the training curricula needed for this new profile qualification.

In section 2, the respondents rank the importance of the followed syntheses:

- Environmental protection;

- Corporate Social Responsibility;

- Business Development;

- Health-Safety and Working Conditions;

- Minimization of resources consumption/zero emissions/circular economy.

By interpreting all data collected, the conclusions are: Health-Safety and Working Conditions are extremely important for the sustainability concept (over 60\%), Environmental Protection (over 50\%) and Business Development (over 40\%) (figure 2).

Section 3 refers to the sustainability concept in the business: $95 \%$ of the companies consider sustainability in their business strategy. The respondents expressed their opinion regarding the existence of a sustainability officer: $53 \%$ of the interviewed companies answered positively, and $47 \%$ of the companies do not agree with such a position. They said that in this position the persons who are in charge of sustainability are either: R\&D Project Manager, HR Manager, General Manager, HR/CSR Manager, CSR and Quality Coordinator.

Depending on the type of the company and their production, most of the companies are certified to one or more than one management systems/guidance The most recurrent management systems/guidance used by companies is ISO $9001 ; 52.6 \%$ of companies use the international standard that specifies requirements

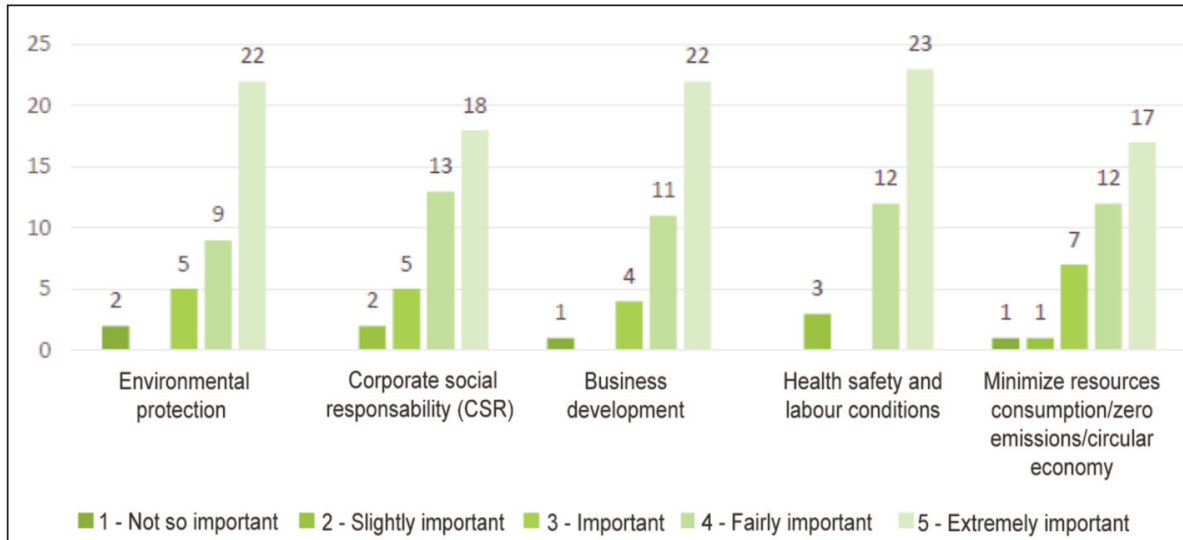

Fig. 2. Sustainability concept in the business (major toipcs) 
for a quality management system. The companies use the standard to demonstrate the ability to provide products and services that meet customer and regulatory obligations (figure 3). Also, $73 \%$ of the respondent companies consider that having a certified management system is essential and needed for achieving sustainable development in their business.

Mainly, $21 \%$ of companies are STeP by OEKO-TEX® (Sustainable Textile Production) certified, which is related to sustainability management in textile production. Other companies $(10.5 \%)$ are certified SA 8000 (Social Accountability 8000), $7.8 \%$ are certified according to OHSAS 18000 - Occupational Health and Safety Assessment Series. The standard ISO 45001 substitutes the OHSAS

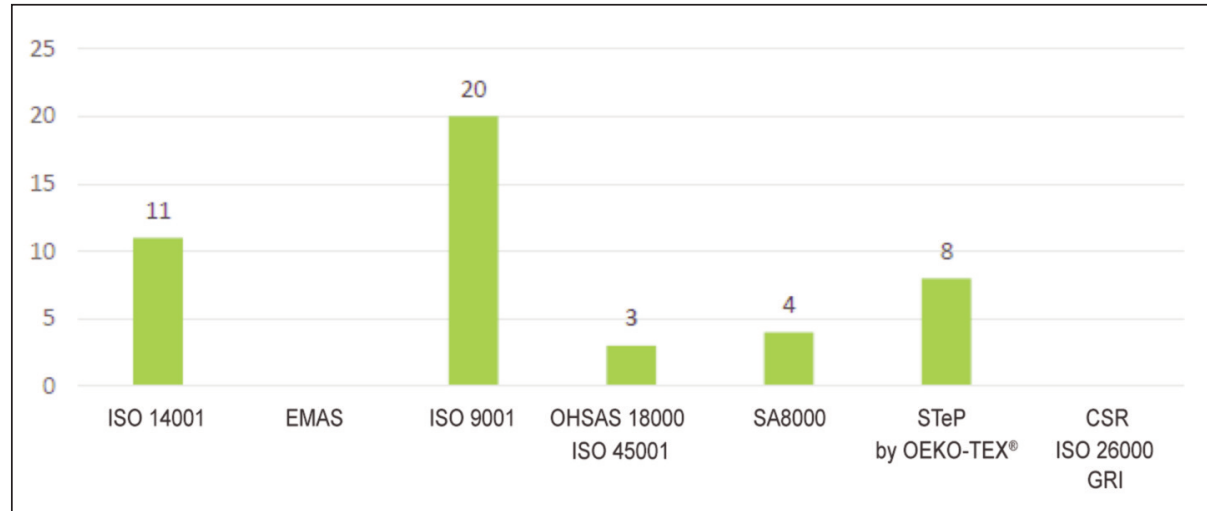

Fig. 3. Management system/guidance certification

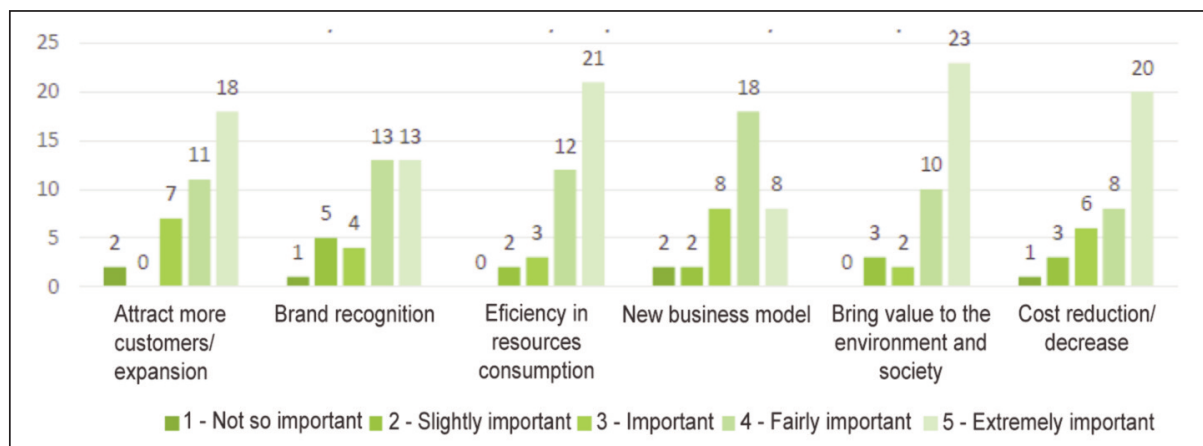

Fig. 4. Importance of sustainability for their company 18001 standard.

Mainly, $73 \%$ of the respondent companies consider that having a certified management system is essential and needed for achieving sustainable development in their business.

In Section 4, the respondents have to appreciate the importance of the sustainability concept. The conclusions are: $60.5 \%$ of companies consider that the sustainability is extremely important in order to Bring value to the environment and society; $55.3 \%$ consider that sustainability is extremely important for the
Efficiency in resources consumption and $52.6 \%$ mention the Cost reduction. Only $34.2 \%$ deem that sustainability is essential for Brand Recognition (figure 4).

In section 5, respondents are asked to list the competencies and skills considered fundamental for the sustainable expert profile (figure 5).

So, $68.4 \%$ of companies consider that the sustainable expert should have competencies and skills in Sustainability (environmental, social and economic) Analysis and Management as extremely important.



Fig. 5. Listed competencies and skills 
$52.6 \%$ of companies also mention Corporate social responsibility; $42.1 \%$ of companies consider Environmental legislation; Health \& Safety Legislation and Industrial Sustainability as important and 39.5\% of companies rate Energy management as extremely important. $50 \%$ of companies consider having skills in Carbon footprint as essential; $44.7 \%$ in Climate change and $42.1 \%$ of companies mention the Sustainable business models, Environmental economics and Social responsibility legislation.

The following skills and competencies were considered with slight importance:

$-23.7 \%$ of companies point to Transport (electric cars, hybrid cars, fuel cells, biofuels, international transport, maritime transport);

- 18.4\% of companies mention Environmental engineering;

- $15.8 \%$ of companies indicate the MFA (material flow analysis); International politics and foreign policy and Systems engineering.

Bellow are shown skills and competencies that were ranked as not so important for the SE $(10.5 \%$ of companies), Energy efficiency and renewable energy, Life cycle assessment (LCA); Sustainable consumption/Sustainable procurement; Ecolabelling/sustainability labels; Circular economy; Supply chain analysis; Environmental economics.

Respondents are increasingly aware of the demands of the market, consumers and their workers. They are investing more in the sustainable certification of their products and in the qualification of their workers in order to become more competitive. $95 \%$ of the companies consider that the Sustainability Expert should hold a qualification. Over $60 \%$ said that a Sustainability expert should hold a qualification, either a higher degree/master of professional degree. In section 6, respondents had to express their opinion regarding online learning: $71 \%$ of the companies felt very confident or confident in online learning, and $29 \%$ answered "not confident".

All answers were attentively interpreted and used to design the "Sustainability Expert" professional qualification profile for the Textile Sectors and the e-learning materials to train him. This person is recommended to:

- Have a bachelor's degree, because he has to communicate and coordinate with management, shareholders, customers and employees to address sustainability issues.

- Develop, implement and evaluate programmes for the employers that support social, environmental, and economic sustainability objectives.

- Have outstanding skills in strategic planning, human resources management, and relationship-building.
The needed topics of training the employee for this new type of qualification are:

- Module 1 - Sustainable Management

- Module 2 - Environmental Performance

- Module 3 - Corporate Social Responsibility

- Module 4 - Circular Economy.

\section{THE ECO TEX PROJECT TRAINING PLATFORM}

The "Training Toolkit" fits the new qualification and targets all education and training entities and other agents related to training/employment (figure 6). The learning units/modules can be used separately for tailor-made training, and for other objectives in support of the implementation of sustainable manufacturing in textile and clothing SME's.

The topics of the training platform is harmonised with the requirements of the European learning system. The courses/training units are developed with multidisciplinary modules, focused on [15]:

- Climate Change

- Circular Economy

- Certifications and Policies

- Manufacturing Systems

- Energy Management

- Environmental Legislation

- Sustainable Business Models.

The platform is developed and technically validated to make sure it accommodates all the needs identified. It enables users to have access to information and data for the enhancement of their skills, knowledge and competencies.

The Sustainability Expert course offers the learners long-term benefits of creating an efficient sustainability approach for their company/business, acknowledging the social and environmental impacts of production and consumption.

On the platform, the users have the possibility to:

- Follow the modules corresponding to the learning paths;

- Build their own self-customised learning paths in order to fill in their own skill and knowledge gaps, selecting the modules they find more appropriate (figure 7).

The learners have available quizzes which evaluate the level of understanding, and if they get good scores to all quizzes, they will be able to get the certificate of Sustainability Expert.

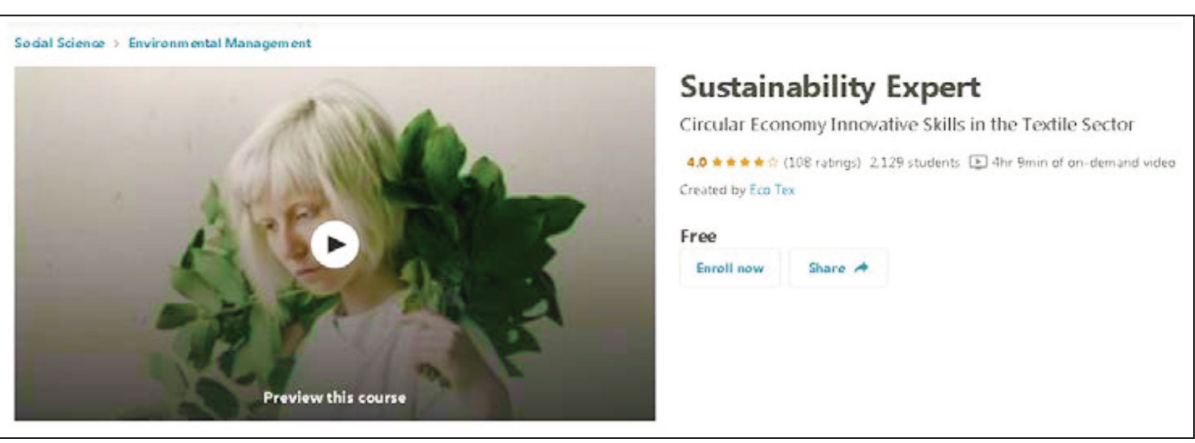

Fig. 6. ECO TEX project training platform [15] 

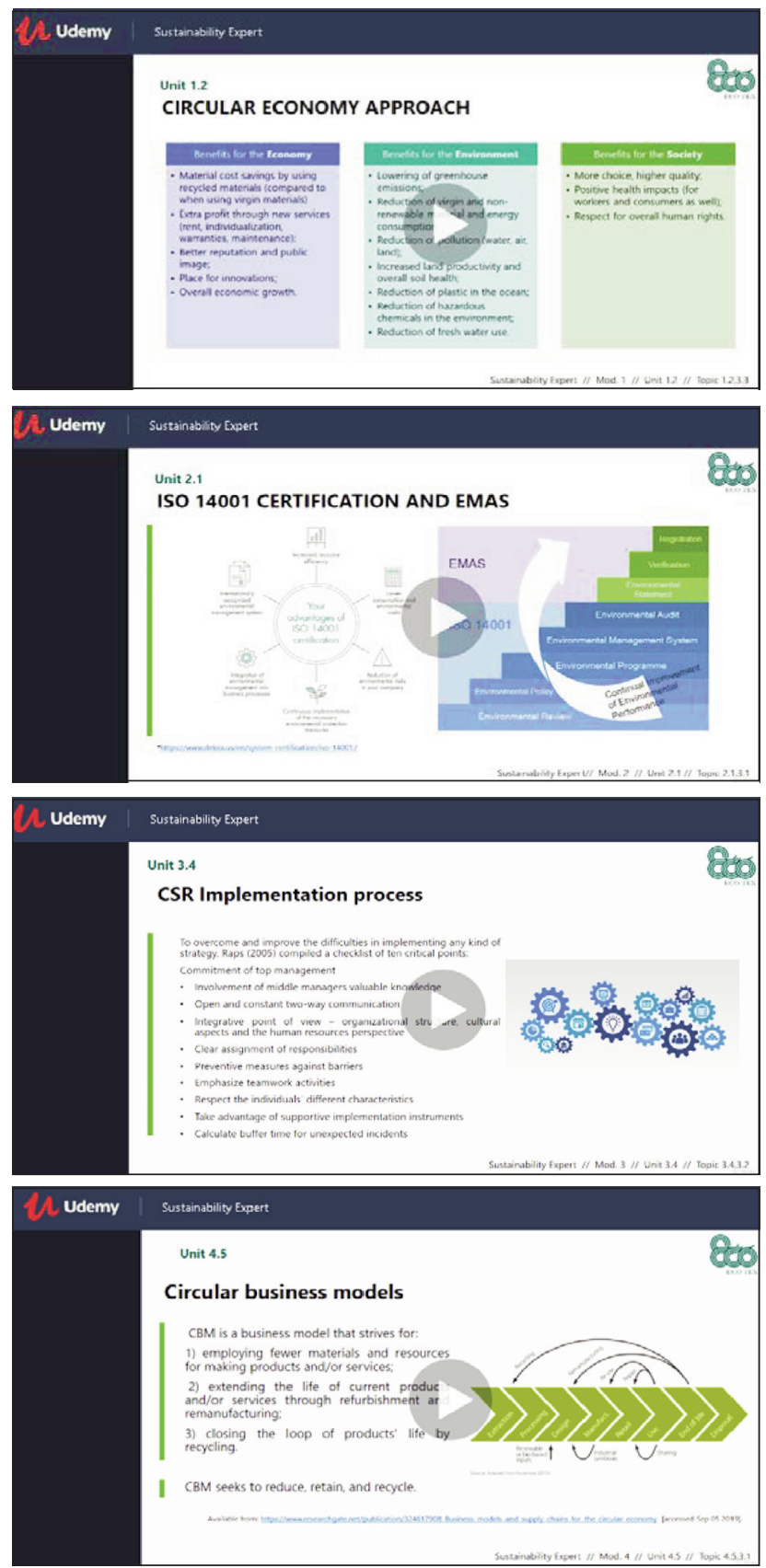

Fig. 7. Insights of the Sustainability Expert course

The platform has e-Courses, a forum for the exchange of news and information related to the sector and for connection with other users for the sector platforms such as EPALE.

The current research contributes to the natural uptake of the EU principles for EQF and ECVET through the production of new innovative curricula and its implementation in the web (e-learning platform) as a user-friendly modern tool for reaching out to the labour market (designers, managers, workers/engineers and students in fields related to textiles and clothing sector).

\section{CONCLUSIONS}

The ECO TEX project offers an instrument for training efficiently and adequately the staff of textile and clothing companies, in circular economy techniques and sustainability design and production. Thus, businesses and employers will not need to spend money, time and effort on, firstly, identifying the needed qualifications, skills and knowledge required for a competitive Sustainability Expert of the textiles sector, and secondly, for training their staff in order to be ready to meet the demands of internationalisation and competitiveness.

Moreover, the skills of the staff and business owners will be upgraded and matched directly to the labour market.

The content of the training units uploaded on the digital platform provides:

- the improvement and extension of high-quality learning opportunities, tailored to the needs of textiles and clothing industry;

- a new high-quality tool for training the staff of textiles SME's in the new business model, the circular one;

- the possibility to establish close cooperation between formal education providers and businesses in order to increase the market relevance of the proposed training toolkit;

- the creation of awareness for the need of a sustainable manufacturing strategy;

- the exploitation of results through European, national and local networks and platforms, enterprises, business organisations, guidance organisations, as well as other relevant media, within and outside Europe;

- the enlargement of networking between the partners.

The ICT tools are there to train the users by applying EQF principles directly. The e-learning content was prepared in six European languages (English, Spanish, Romanian, Portuguese, Latvian and Greek), with video explanations and multiple-choice tests in each module. The project outcomes had a good impact on various category of staff in the textile sector, business owners in this industry, students in fields related to the textile sector, individuals with interest in joining the textile sector, who participated in the multiplier events and in the project pilot phase.

\section{ACKNOLEDGEMENT}

This paper has the support of information of the project ERASMUS+, Key Action2-Strategic Partnerships nr. 20171-ES01-KA202-038419, "Circular ECOnomy Innovative Skills in the TEXtile Sector", Acronym ECOTEX.

\section{REFERENCES}

[1] Caldwell, L.K., The Concept of Sustainability: A Critical Approach, In: Lemons, J., Westra, L., Goodland, R., (eds) Ecological Sustainability and Integrity: Concepts and Approaches. Environmental Science and Technology Library, Springer, Dordrecht, 1998, 13, https://doi.org/10.1007/978-94-017-1337-5_1 
[2] European Commission, Sustainable development, Available at: http://ec.europa.eu/trade/policy/policy-making/ sustainable-development/\#_trade-agreements [Accessed February 2020]

[3] Ozek, H.Z., Sustainability: Increasing Impact on Textile and Apparel Industry, In: J. Textile Eng. Fashion Technol., 2017, 2, 5, 76, https://doi.org/10.15406/jteft.2017.02.00076

[4] Tedeschi, L., Muir, J.P., Fox, D.G., Riley, D.G., Future implications for animal production: a perspective on sustainable livestock intensification, In: Conference Proc. 52nd Annual Meeting Brazilian Society of Animal Science, 2015, 52

[5] EURATEX Annual Report 2018, The European Apparel and Textile Confederation, 2018, Available at: https://euratex.eu/wp-content/uploads/2019/05/Euratex-annual-report-2018-LR.pdf [Accessed on December $5^{\text {th }}$ 2019]

[6] EURATEX Key Figures 2019, Available at: https://euratex.eu/wp-content/uploads/EURATEX-Facts-Key-Figures2020-LQ.pdf [Accessed on June 2020]

[7] Malik, A., Akhtar, R., Grohmann, E., Environmental deterioration and human health: Natural and anthropogenic determinants, In: Environmental Deterioration and Human Health: Natural and Anthropogenic Determinants, 2014, 1, 421, http://doi.org/10.1007/978-94-007-7890-0

[8] Koszewska, M., Social and Eco-labelling of Textile and Clothing Goods as Means of Communication and Product Differentiation, In: Fibres \& Textiles in Eastern Europe, 2011, 19, 4 (87), 20-26

[9] Poonam, K., Saroj, S.J.S., Neelam, M.R., Eco - Textiles: For Sustainable Development, In: International Journal of Scientific \& Engineering Research, 2013, 4, 4

[10] Adıgüzel, F., Linkowski, C., Olson, E., Do Sustainability Labels Make Us More Negligent? Rebound and Moral Licensing Effects in the Clothing Industry, In: Muthu, S., Gardetti, M. (eds) Sustainability in the Textile and Apparel Industries. Sustainable Textiles: Production, Processing, Manufacturing \& Chemistry, Springer, Cham, 2020, ISBN 978-3-030-38531-6, https://doi-org.am.e-nformation.ro/10.1007/978-3-030-38532-3_1

[11] European Commission, Directorate-General for Internal Market, Industry, Entrepreneurship and SMEs, Support Report Mapping Sustainable Fashion Opportunities for SMES, May 2019, Available at: https://ec.europa.eu/growth/ content/study-mapping-sustainable-fashion-opportunities-smes_en [Accessed February 2020]

[12] Skills4Smart TCLF 2030 project, Available at: http://www.s4tclfblueprint.eu/ [Accessed February 2020]

[13] ECOTEX project, Available at: http://www.ecotexerasmus.eu/en/ [Accessed February 2020]

[14] CosTUmE project, Available at: http://clothingtechnician.eu/ [Accessed February 2020]

[15] ECO-TEX Udemy platform, Available at: https://www.udemy.com/course/textilesustainabilityexpert/ [Accessed February 2020]

Authors:

MANUELA AVADANEI ${ }^{1}$, SABINA OLARU ${ }^{2}$, IRINA IONESCU ${ }^{1}$, MARIANA URSACHE${ }^{1}$, LUMINITA CIOBANU ${ }^{1}$, LIDIA ALEXA ${ }^{1}$, ALEXANDRA LUCA ${ }^{1}$, MONICA OLMOS $^{3}$, THEOFILOS ASLANIDIS ${ }^{4}$, DANA BELAKOVA ${ }^{5}$, CÉSAR SILVA ${ }^{6}$

${ }^{1}$ Gheorghe Asachi Technical University of lasi, Faculty of Industrial Design and Business Management, 29 Bld. D. Mangeron, 700050, lași, Romania

${ }^{2}$ National Research \& Development Institute for Textiles and Leather, 16 Lucretiu Patrascanu street, 030508 Bucharest, Romania e-mail: sabina.olaru@incdtp.ro

${ }^{3}$ CONFEDERACION DE LA INDUSTRIA TEXTIL ASOCIACION, 30 Sant Quirze street, 08210, Sabadell, Spain

${ }^{4}$ Hellenic Fashion Industry Association - SEPEE, 51 Ermou street, Athens, GR 10563, Greece

${ }^{5}$ RIGAS TEHNISKA UNIVERSITATE, 1 Kalku street, LV-1658, Riga, Latvia

${ }^{6}$ Centro Tecnológico Industrias Têxtil Vestuário Portugal - CITEVE, 2785 Rua Fernando Mesquita strret, 4760-034, Vila Nova de Famalicão, Portugal

Corresponding author:

MANUELA AVADANEI

e-mail: mavad@tex.tuiasi.ro 